\title{
J. J. ルソーにおける身体と教育：公教育論に注目して
}

\author{
佐々木 究
}

Kyu Sasaki: Human body and education in J. J. Rousseau: focussing on the discusses of public éducation. Japan J. Phys. Educ. Hlth. Sport Sci., 54: 279-291, December, 2009.

\begin{abstract}
This paper is part of a study performed to clarify certain aspects of primitive thought related to physical education (PE), as outlined in the work of Jean-Jacques Rousseau.

Some studies of Rousseau have focused on PE, but in my view these are not based on the positive foundation, and there is no reference to the term "physical education (éducation physique)" in his works. Nevertheless, it is possible to demonstrate connections between Rousseau and PE. It is evident that the "father of modern PE", GutsMuths, was influenced by Rousseau, and many discussions in this field have, in fact, been based on Rousseau. This study focuses not on PE itself, but on a prototype concept that is recognizable in Rousseau's works.

For this purpose, this paper attempts to analyze the context, especially public education focusing on the human body. In general, the terms "human body (corps)" and "education (éducation)" are understood as the elements of PE, and discussion of public education can be seen as one of the bases of Rousseau's thoughts about education, containing some important descriptions about the human body.

The main points presented in this paper are as follow:

Body exercise (exercices corporels) in public education, which has been accepted as the "PE of Rousseau", is an approach to education with two purposes: moral and physical. Exercise is based on "negative education" aiming at the "child", which is one of the main concepts of Rousseau's education thought. Furthermore, some value is placed on the whole process, where public education goes on to developing patriotism (l'amour de la patrie) in children (i.e. future citizens). Finally, exercise, a method of education, is balanced between the demand for public education and the restriction imposed by negative education.
\end{abstract}

Key words : physical education, negative education, method of education, exercise キーワード：体育，消極教育，教育方法，訓練

\section{はじめに}

本稿は，近代思想家の一人であり教育書『エ ミール』の著者としても知られるジャン = ジャッ ク・ルソー（Rousseau, Jean-Jacques: 1712-1778）に 着目し, 彼の教育思想における身体と教育との概 念的連関性を, 彼の思想全体を視野に置きつつ検 討するものであり，とくに公教育論に取材するも のである.ルソーは従来の体育史研究においても 取り上げられてきているが，実のところ，彼の 「体育」への言及は自明のものとは言えないだろ
う。むしろ彼の役割は，近代社会において「体育」 が制度として成立する思想的基盤を提供するもの と見なすべきではないか.こうした考えのもと， 従来，「体育」への言及であると見なされてきたテ クストをフランス語原典に立ち返って検討し，ル ソーが確実に用いている「身体 corps」および「教 育 éducation」という用語の相互連関, さらにはこ れらの用語に関わる諸概念を精査することで，ル ソーが準備した近代体育の思想的基盤を明らかに していきたい.

ルソーは, 18 世紀ヨーロッパで活動した, いわ ゆる啓蒙期を代表する思想家の一人である。彼に
筑波大学大学院人間総合科学研究科

干 305-8574 茨城県つくば市天王台 1-1-1

連絡先 佐々木 究
Doctoral Program in Graduate School of Comprehensive Human Sciences, University of Tsukuba 1-1-1 Tennodai, Tsukuba, Ibaraki 305-8574

Correspondingauthor sasakikyu0710@yahoo.co.jp 
よって遺された多くの著作は，わが国でも広く紹 介され, 教育学, 政治学分野を中心に現在まで読 み継がれてきている。 また, 体育学分野でも, ル ソーが「体育」の教育的意義を明確にしたこと, あるいは「近代体育の父」グーツムーツらが彼の 影響下にあったことなどの指摘があり，とくに体 育 (思想) 史研究では中心的な研究課題の一つと 目されている，ただし，従来の体育（思想）史で は，ルソーにおける「体育」が自明のものとして 取り扱われている点に概念論上の問題がある.

「体育」という用語の成立が比較的新しいもので あることは，今や周知の事実であると言えよう. 正確な初出については未だ定説を見るに至ってい ないが, 清水重勇（成田ほか, 1975）は，1761 年 のラシャロッテ (La Chalotais, Louis-Rene de Caradeuc de 1701-1785）にその創出の功を帰して いる注1)。この用例は, The Oxford English Dictionary（Supplement, 1981, vol. 3, p. 460）が例示 する 1838 年の Smiles における‘physical education’の 用例に先立つこと 77 年であり,「体育（身体教 育)」という用語の成立を，18 世紀フランス語の テクストに求めることにはかなりの妥当性がある と思われる注 ${ }^{2}$ 。こうしたことから，「体育（身体 教育)」という用語/概念は注 3 ), せいぜい 250 年ほ どの語史をもつに過ぎないのであり，ルソーはま さしく体育黎明期の思想家であると言えるのであ る.

しかし，実のところ，彼の著作において「体育 l'éducation physique」という用語を見出すことはで きない.すなわち，「ルソーにおける体育論」とい う論題はそもそも用語上の根拠をもっていないの であって，この論題の成立を無批判に認めること はできないのである.にもかかわらず，ルソーに おける「体育」を論じようとする研究は少なくな いし，「ルソーにおける体育重視」という指摘もま た，学問分野を問わず，見出すことができるので ある（桑原ほか, 1977, p. 341; 新堀, 1979, p. 219 な ど).

こうした議論は，無自覚にルソーにおける「体 育」を所与のものとして取り扱っている場合もあ るが, 彼のテクストにおける文脈から彼の「体育
論」を剔抉するという方法論に基づいていると考 えられる。つまり，ルソーの著作に「体育 l'éducation physique」という用語を直接見いだせないとし ても，われわれの目から見て「体育論」と見なせ る論述を認めることができるというのである.

確かにルソーの議論には, 後代への影響関係に おいて, 体育論の思想的前駆と認め得る論点が看 取されるし，また，体育についても無前提的に成 立したとするより何らかの前段階があったと想定 するほうが妥当であろう。実際，ルソーは，体育 の外部にありながら，なお一定の体育的な準位に 達していると見ることができるのである. 問題は, ルソーのテクストに「体育 l'éducation physique」と いう用語が見出せない以上，それをどのようにし て確定するかという方法論である.

ところで, 体育概念が歴史的に多義性を帯びて きたことは，改めて指摘するまでもないだろう. たとえば木下（1971）は，近代のわが国における 「体育」の用例を綿密に検討し，教育概念として 出立した「体育」が多義化する過程，あるいはそ の意味を変容させていく過程を実証的に明らかに している。この点を踏まえれば，体育概念に打け る普遍的かつ実定的な根拠の特定には困難が予想 されることになり，本研究においても方法論的な 問題を惹起することになるだろう。すなわち，そ もそも「体育」という用語の成立以前において 「体育」を論ずることは可能なのか，といった難問 である。

そこで本研究では，「身体」および「教育」を 「体育」へ接近するための方法論的視座として設 定することで，上述の難問の克服を試みることと したい，というのも，「体育」は，もともと「身体 （的）教育」を含意する教育概念として出立した ことが歴史的事実として認められており，今日で む「身体」と「教育」とは体育概念を形成する二 大要素であると見なすことができるからである. そして，このような視座に立てば，ルソーの著作 に扔いて，これら「身体 corps」抢よび「教育 éducation」の用例は，十分に見出すことができる のである.

こうした本研究における方法論は，「体育という 
用語の成立以前において体育を論ずることは可能 か」といった難問を克服するための有力な試みで あると言えよう。ルソーにおける「身体と教育」 を巡る言説を検討することは, 実際には用語とし て存在していない「体育」の場合と異なり，テク ストに基づく実証的遂行が可能である。こうした 接近法によって, 用語成立以前, すなわち「前 体育的」状況での体育的実相を明らかにする可能 性が拓けてくると考えられるのである.

本研究の課題においてとくに注目するのが，ル ソーの「公教育」に関する一連の議論である. 公 教育論は, 本論でも述べるように, 私教育論とと もにルソー教育思想における主柱の一つと認めら れており，ときにルソー教育思想全体における主 流とも目されながら読解における重要な論件と なってきた。 そして，そこでの中核的な焦点とし

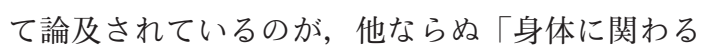
教育」なのである。ルソーにおける公教育論は, 私教育論と比較するとき, 確かに質・量ともに十 分とは言えないが，しかし，ここでは「身体に関 わる教育」の意義がより強く浮き彫りにされてい るとも言えるのであって, 公教育論は, 本研究が 展望する「前一体育的」な思想状況を照らし出す うえでも，検討されるべき重要な論点なのである.

ルソー公教育論で展開される「身体に関わる教 育」は，本論で見るように，政治論そのものに よって支持されており, 社会全体における位置づ けを明らかにするものとなっている。一般社会に 対する「体育 (身体教育)」の貢献は, 今なお問 われるべき現代的課題の一つであるが，本稿での 議論は, この課題に新たな視点を提供する可能性 を有している，ただし従来の研究では，ルソー公 教育論に打ける「体育重視」という指摘はしばし ば為されてきたが（坂入, 1973; 江坂, 1973 など), 「身体と教育」に焦点化し, その論理的関連性か ら考察するという厳密な方法論はとられていない. そこで本稿では，ルソー公教育論の具体的文脈に 着目しつつ，身体への教育論的言及を精查するこ と, すなわち, ルソー公教育論における「身体」 的文脈を, ルソー教育思想の論理によって跡づけ ることで,「前一体育的」状況における体育的思
想状況を浮き彫りにしょうとするのである.

なお，本論の考察に先立ち，ルソー身体論への 基本的な視座を示しておきたい。すなわち，ル ソーは，心身を二元論的に把握しており，「身体 corps」は元来，延長実体である「死すべき物質 matière」の「集合体」として認識されている.「生 命体 corps vivant」は，生命原理とも言うべき思惟 実体「魂 âme」がこれと結びつくことで成立する. それぞれの生命体は,「魂」の能力と釣り合いの取 れた固有の「組織された organisés」「身体」を与 えられており，人間も同様である。ルソーにおい て「身体」を問うことは，原理論的には，人間身 体に付与された構造とそれが可能とする機能，お よび各位相を貫く性質を問うことになるのである. この視点は, 本論の考察に直接関与することがな いが, 本論における論議の補助線となっているこ とを指摘しておく注 4 .

\section{I＼cjkstart公教育論における身体性}

一般に公教育は，国家や地方自治体などの公的 組織によって運営される公共の教育制度, と定義 されている。ただし, 現代のわれわれが見る公教 育制度が実現するのは 19 世紀も後半になってから である（五十嵐ほか, 1990）。ルソーが問うのは, 同じく国家によって為される教育であるが，近代 社会成立以前の旧制度を前提とする公教育につい てである。しかし，彼の主張は一見すると奇妙な ものである. と言うのも，ルソーによれば，彼の 時代に公教育は「すはや存在しない」（傍点引用 者）というのである（ルソー, 1762,『エミール』 O. C., t. IV, p. 250; 全集第六巻 p. 22） 注 5).

ルソーは, かつて公教育が行われた「国民」と しては, クレタ人, スパルタ人, 古代ペルシア人 のみを認めている（ルソー, 1755, 『政治経済論』 （以下『政経論』之略す）O.C., t. III, p.261 全集第 五巻 p. 85). 彼によれば, 公教育の主体たる「祖 国 patrie」とその構成員たる「市民 citoyens」が失 われてすでに久しく,「もはや祖国のないところで 市民はありえない」のである（ルソー, 1762, 『エ ミール』O.C., t. IV, p. 250 全集第六巻 p. 22). ル 
ソーが，自ら生きる時代にもはや公教育は存在し ないと主張するのは，公教育が前提すべき「祖国 と「市民」の存在がいまは失われてしまっている， という時代認識に基づくのである。彼の教育論で ある『エミール』が，公教育ではなく私教育を主 題として展開されているのも, 実はこうした認識 が背景にあると考えられるのである.

したがって, ルソーでの公教育論は, 教育論的 文脈ではなく，まずは政治論の範疇で議論される ことになる。彼自身の時代認識にあって公教育の 前提となる祖国と市民が存在しない以上，考察の 対象となるのは彼が直面する現実の国家ではあり えず，想定される理想社会ないし理想国家となら ざるを得ないからである。こうした理想国家・社 会における政治論的範疇としての公教育は, 国家 の構成員たる「市民」の育成を第一の課題とする ことになるが，具体的な議論は，『政経論』、『ポー ランド統治考』（以下『統治考』と略す）などに 見ることができる（桑原ほか, 1977, p. 332 など）.

両著作の政治論的位置づけについては諸説ある ものの，ルソー政治論の代表作である『社会契約 論』（以下『契約論』と略す）を中核と位置づけ た上で，『政経論』をこれに至る過渡的な作品と し，後年の著作である『統治考』をその現実への 適用と見ることは，ひろく認められるところであ る。また，『契約論』が政治社会の根本構造を問 うことを主題とするのに対し，『政経論』が統治の 原則を問うているという主題上の違いはあるもの の，ともに普遍的・一般的なレベルにおいて議論 を展開している点では共通しており，『統治考』に おいても同様である注 6)。つまり，ルソーの政治論 的著作は，いずれも個別的政策を論じたり提言し たりするものではなく，あくまでも原則論を問う 理論的性格を有しているのである。こうした政治 論的著作において言及される公教育論は，当然の ことながら，政治論的文脈のなかで語られること になるし，それぞれの著作の主題に合致する限り において言及されることになる。従って，公教育 システムに打ける具体的な教育課程や教育方法に 関する言及は必ずしも十分とは言えないのであ る注 7).
しかし，このことはルソーが公教育を軽視して いることを意味しない。ルソーは，『エミール』の 冒頭で，「人間をつくるか，市民をつくるか，その いずれかを選択せねばならない」とし（ルソー, 1762,『エミール』O.C., t. IV, p. 248 全集第六巻 p. 20)，教育目的の設定に関わって私教育之公教育 を，いわば二律背反的に提示しているが，冒頭に 述べたように，『エミール』における私教育の選択 は，すでに「公教育が存在しない」という現状認 識を踏まえた，いわば消去法的な決断なのであっ て，公教育の現実的な実現が困難であるという彼 の時代認識によるものと言えるのである。じっさ いルソーは，後年，あらためて公教育論を敷衍す るべく，両教育形態を比較する著作の執筆を企図 していたとされており（Vaughan, 1962, vol. I, p. 234, vol. II, p. 142)，また，論理構成上からみても，私 教育論に公教育論に対する優越を認めることは困 難と考えられるのである.

一方，これまでのルソー研究でも，具体的な論 拠や解釈に違いはあるものの，私教育よりも公教 育論に優位を認める指摘が多くなされており，極 端な主張としては，『エミール』を公教育論の「代 替物」とする見解も提出されているのである注 ${ }^{8)}$. ただし私見によれば，こうした見解も，ルソー教 育論の総体的理解としては不十分であると思われ る. 公教育および私教育については，一方を他方 に吸収し解消しょうとする解釈は，それぞれの教 育形態のよって立つ基盤の相違を無視することに なりかねないのである。

しかし，これまでのところ，両教育形態の機能 分化に打ける統合的解釈については未だ確定的見 解は示されていないし，さらに，ルソー教育思想 の全体像についても, 究極的にはルソー解釈の根 本問題である「ルソー問題」に帰着するかもしれ ず注 9)，その解決は本論考の射程を超えるものと言 わざるを得ない。したがって，本稿では，さしあ たり，両教育論を等しくルソー教育思想の「柱」 と位置づけたうえで注 10)，まずは公教育論に議論 を焦点化し，そこに立ち現れてくる身体性を指標 としながら, 公教育論に内在するルソー的論理の 解明を試みることにしたい。 
上述したように，ルソー政治論は，社会や国家， あるいは統治の当為を問う一般的性格を持つもの であり，政治や統治の具体的手法を論ずるもので はない，著作の性格がこうしたものである以上， 公教育論において育成対象となる市民およびその 身体についても，政治論的意図に合致する側面か ら言及されることになる。とはいえ，こうした公 教育論での身体への言及は, 体育思想への重要な 契機となるのであって, 体育学的に注目される必 要がある. 確かに, 『エミール』の場合とは異な り, 教育課程などへの言及は不十分ではあるが皆 無ではなく，そこに立ち現れる「身体」への言及 は,「ルソー公教育論に抢ける体育重視」という従 来からの指摘以上に, 彼が「身体」に付与してい る教育的意義の度合を推し量ることができるので ある。

「身体」については, 『統治考』の「教育 ÉDUCATION」の項目に扔いて,「教育のもっとも 重要な部分」として次のように言及されている.

すべての学院に子供たちのための体育館 gymnase, つまり身体訓練の場 lieu d'exercices corporels をつくらなければならない。このきわ めて軽視されてきた条項は, 私見によれば, 教育のもっとも重要な部分をなすのであり, それはたんに強健で健全な体質を形成する former des temperamens robustes et sains ためばか りか, それ以上に, 無視されているか, また は言葉のみで守られたことのない街学的で空 しいあれこれの戒律によってしか果たされて いない，倫理的な目的 l'objet moral のためな のである（ルソー, 1771 注 11), 『統治考』O. C., t. III, pp. 967-968 全集第五巻 p. 378).

うえの記述は,ルソーにおける「体育重視」の 有力な論拠とされるものであるが，この引用にお ける公教育での「身体」は注 ${ }^{12)}$, 教育方法および 教育目標それぞれの視点から二義的に捉えられて いる。 すなわち, 教育方法の範疇にある訓練の対 象としての「身体」と, 明示化されてはいないが 教育目標である「強健で健全な体質」を担う基体
としての「身体」である，さらに身体の育成に対 して「倫理的な目的」が附与されることで注 ${ }^{13)}$, 身体をめぐる論点が一層複合化されているのであ る。では，身体をめぐるこうした複合的な「目 的一方法連関」には，どのようなルソー的論理が 内在しているのだろうか. 次節において考察を進 めることとしょう.

\section{II「消極教育」の概念と「身体」}

前節で触れた「目的－方法連関」の一方，すな わち「身体訓練」が身体の強健や健全な体質を育 成するうえで有効な教育方法であることについて は, ルソーにおいても自明視されていると言って よい注 14).しかし，「身体訓練」による「倫理的な 目的」の達成という「目的一方法連関」について は，直ちにこれを自明であるとすることはできな い. 身体訓練が倫理的目的のもとになされるとは, すなわち, 身体訓練の結果として, 何らかの倫理 性が育成されるという連関性を認めるということ である。このような因果律の内的機序を明らかに することは容易ではないが，しかし，ルソーがこ のような連関性の成立を想定した理由については, 彼の教育思想の論理に基づく合理的説明が可能で あると思われる。

ルソーは，先の引用文に続き，「訓練 exercices」 の意義を次のように敷衍している.

良き教育とは消極的なもの être negative でな ければならぬ, と私が何度繰り返し述べても,

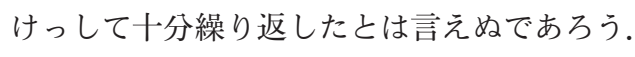
悪徳 les vices が生まれるのを妨げよ.そうす れば，徳 la vertuのために十分尽くしたこと になるのだ。その方法は, 良き公教育 éducation publique にあってはもっとも容易なもの である。それは，‥ (中略) ‥退屈な勉強 étudesによってではない. そうではなく, 長 ずるにつれて彼らの身体 leur corps が必要と するようになる動きまわりたい de s'agiter と いう欲求 besoin を満たしてやることによって, 彼らの気に入ることになる, 訓練 des exerci- 
ces によってなのである（ルソー, 1771，『統治 考』 O. C., t. III, p. 968 全集第五巻 p. 378) 注 15).

先に見たように，「身体訓練」には「倫理的な 目的」が設定されていたが，ここでは，ルソーに 特徵的な「消極的な教育」という考えに基づいて， 倫理的目的の設定理由が「悪徳 les vices」の生成 を妨げるためである，とされている。つまり，「徳 la vertu」の積極的な育成を図るというのではなく 「悪徳」を防ぐことで結果的に「徳」の育成に貢 献しょうというのである。「消極的な教育」は，必 ずしも徳の生成を含意しないが，悪徳の生成を妨 げることで「徳のために十分尽くす」ことを求め ているのであり，「身体訓練」は，こうした当為之 しての教育の消極性に基づく具体的方法と見るこ とができるのである.

こうした当為としての消極性に基づく教育案は, ルソーの教育思想における方法原理として定式化 されていると言ってよい。いわゆる「消極教育」 であるが，それは，図式的に言えば，未だ「理性 raison」の発現を見ず，「知的な対象」（ルソー, 1763，『クリストフ・ド・ボーモンへの手紙』（以 下『ボーモンへの手紙』と略す) 注 16) O. C., t. IV, p. 951 全集第七巻 p. 470）や社会的・道徳的な関係 性を認識し得ない「子ども」に対し注 17)，「徳」や 「真理」を教えようとする代わりに「悪徳」や「詋 謬 l'erreur」から彼らを守ることを主眼とする, 準 備教育とも言うべき性格のものである注 ${ }^{18)}$.

ルソーは，成長期にある人間の発育過程をおお むね五段階に区切って把握していると考えられて おり，一般にそれぞれの段階は，(1)乳児期，(2)少 年期，(3)成童期，(4)思春期，(5)青年期と名付けら れる注 19). また, ある段階から次の段階への移行 過程は概してゆるやかにかつ連続的に展開するが, 第三段階と第四段階との間には画然たる質的差異 があるとされる、ルソーが想定する「子ども」期 は, この「差異」が顕現化する以前の(1)乳児期か ら(3)成童期にいたる三段階を指す。彼によれば, 人間の感受性は漸進的に展開し, 最高次の認識能 力である「理性」も後天的にしか発現しないので
あるが，発育過程の第四段階における画期は，こ の「理性」の覚醒と「社会関係」「道徳性」への 感受性の開放によって達成されるのである。した がってルソーにおいて「子ども」は，これらの感 受性や理性を未だ発現していない存在と言うこと ができ，消極教育は，このような理解に基づく固 有の教育案と見ることができるのである.

ところで，ルソー思想の根本には，「自然 $=$ 善」 対「現実の人間 $=$ 悪」という二項対立的認識が存 在しており，消極教育もこの認識に基づいて成立 するものと言うことができる（原, 1975; Grimsley, 1973 などを参照）。実際，ルソーは，人間も本来 的には「善」なる存在であること，しかし，同時 に，人間が現実の悪しき社会状態において「堕落」 を余儀なくされていることを指摘し，「悪徳の入る 入り口を閉ざしてください，そうすれば人間の心 は善良です」と述へ，そのための「最良の」ある いは「唯一の良き教育」として消極教育を位置づ けているのである（ルソー, 1763, 『ボーモンへの 手紙』O.C., t. IV, p.945 全集第七巻 p. 462).

こうした消極教育が展開されるにあたっては, 人間の発育段階に即した，あるいはこれを前提と したものであることが求められるだろう。という のも，ルソーによれば，人間としての理性が目覚 めるまでの時期は，先に見たように，「真」や 「善」を認識するに至らない時期であり，「誤謬と 悪徳とが芽ばえるのに，これを絶滅するための道 具をまだもてない」時期であって（ルソー, 1762, 『エミール』O.C., t. IV, p. 323 全集第六巻 p. 102), 「悪徳を免れさせる」という目的を達成するには, こうした子ども期の特性を認識し，それに応じた 注意深い教育が必要とされるからである。このこ とは，ルソーが，消極教育を「理性を準備する」 ものと規定し，その意義を，「美徳を与えないが， 悪徳を予防します。それは真理を教えないが，䛊 謬から守ります」としていることからも明らかで あろう（ルソー, 1763, 『ボーモンへの手紙』O.C., t. IV, p. 945 全集第七巻 p. 462).

ただし，消極教育は，字義通りには「何もしな い」あるいは「何もさせない」ことを主張する教 育原理とも見ることができるが（ルソー, 1762，『エ 
ミール』O.C., t. IV, p. 323 全集第六巻 p. 102), 無 限定的に何むしない，ということを意味していな い（原, 1975, pp. 286-288）。ルソーによれば，消極 教育が「消極的」であるべきなのは，「しかるべき 年齢に達する以前に精神を形成」することや，「人 間の義務に関する認識を（未成長の）子どもに与 えようとする」(括弧内引用者) ことに対してであ り,「知識の道具である諸器官を完成」させること や，長じてから「真実」や「善」に導きうるよう に「子どもをなじませておく」ことについては極 めて肯定的なのである（ルソー, 1763,『ボーモンへ の手紙』O.C., t. IV, p. 945 全集第七巻 p. 462).こ うした主張は, 人間の発達段階についての認識か ら導かれる帰結として妥当性を持っており, ル ソーは, いわば「レディネス readiness」（五十嵐 ほか, 1990）に即した教育を主張していると言うこ とができるのである（原, 1975, pp. 289-293）.

このように消極教育は子ども期において重要な 役割を担っているが，それを展開するにあたって 求められる具体的な教育方法が身体的な諸活動で あり，先に見た「身体訓練」なのである．子ども は, 精神的な側面に抢いては教育的レディネスに おいて未成熟であるが, 他方, 身体的な側面にお いては, すでに十分に教育可能な状態にあること を, ルソー自身, 繰り返し指摘しているのである (ルソー, 1762, 『エミール』O. C., t. IV, p. 254, 312, 429, 全集第六巻 p. 26, 89, 216 など). ルソーは, 子どもの内部に身体的運動を志向する「推進力 l'impulsion」の存在をはっきりと認め（ルソー, 1762,『エミール』O.C., t. IV, p. 254 全集第六巻 p. 26) 注 20), 「生徒の身体を, 器官を, 感覚を, 力を 鍛えなさい Exercez son corps, ses organes, ses sens, ses forces. しかし, 彼の魂は son ame できるだけ長 く無為に oisive しておきなさい」と述べることで (ルソー, 1762, 『エミール』O.C., t. IV, p. 324 全集 第六巻 p. 103), 消極教育において採られるべき方 向性を具体的に指示している.すなわち身体活動 は，子ども期における消極教育の具体的方法とし て, 明確に位置づけられているのである.

以上見てきたように，消極教育は，身体活動を 方法とすることで器官や感覚や力の場としての身
体の育成を図る役割が附与されているのであり， 身体に関わる教育という面では，極めて積極性を 有していると言えるのである。消極教育における 身体活動は，ルソー教育論において，いわば方法 的な原理として機能しており，教師による周到な 教育的な場の設定（子どもを取り巻く人的・物的 環境の整備）によって有効な展開が可能となるの である注 21)。その意味で，消極教育は，「消極的」 という字義に反し, 高度に人為的に組織された教 育的営みであり, 体育学的視点からは, 身体と教 育とを結ぶ教育方法として位置づけることができ る。公教育論の文脈で見た教育方法としての「身 体訓練」の意義は, 以上のような消極教育に抢け る論理によって支えられていると考えられるので ある注 22)。

\section{III 公教育論における身体性}

前節では，公教育における身体訓練に関して， それを教育方法として組み込むルソーの論理的枠 組みを見てきた。身体訓練は, 器官や感覚や力の 場である身体自体に関わる目的と「悪徳からの免 除」といった倫理的目的とによる複合性のもとで, 教育方法としての位置を与えられていることを明 らかにしたが, 消極教育をはじめとするルソー教 育論の論理は, 教育方法としての「身体訓練」の 妥当性を明確に保証していると言えよう。

ただし本節では，以上の考察を踏まえ，さらに もう一歩踏み込んだ検討を試みておきたい。言 うのも，ルソー公教育論の文脈では，先に見た引 用文に続いて，以下のように言及されているから である。

家庭内での教育のほうを好み, 自分たちの眼 の届くところで自分の子どもに教育を授けた いと考える両親であっても, やはり，この訓 練 ces exercicesに子どもを送らねばならない. …(中略) …と言うのも，ここではたんに 子どもを勉強させ, 強健な体格をつくり former une constitution robuste, 彼らを敏捷です 
らりとした体にする les rendre agiles et découplésことだけが問題なのではなく, 規則 la régle, 平等 l'égalité, 同胞愛 la fraternité, 競争 concurrences に早くから慣れさせ accoutumer，同国人の眼差の下に生き vivre sous les yeux de leur concitoyens，公の称讃を欲するよ うに desirer l'approbation publique 慣らすこと が, 問題なのだからである（ルソー, 1771, 『統 治考』O. C., t. III, p. 968 全集第五巻 pp. 378379).

これまで見てきたところでは，「身体訓練」は消 極教育の要請に基づき，「悪徳」や「誤謬」から 子どもを保護することで「倫理的な目的」に寄与 するものと理解できた。 それは, 積極的に価值を 実現するよりも，むしろ負の価值への危険を免れ させることに主眼があった。しかし，上に引用し た言葉からは, 消極教育が含意しないはずの積極 的価值を実現しようとする意図が読み取れるので ある。このことは，どのように理解するべきだろ うか注 23).

ルソーによれば，子どもは善や徳の何たるかを 知ることができないため, 本性上, 彼らの行為が 「倫理的に善 moralement bonne」であることはでき ない.しかし，一方でルソーは，「心がまだなにひ とつ感ずることのない年齢にあっては, 善い行為 を子どもに模倣させねばならない」とも述べてい る. と言うのも，「まずその習慣をつけて leur donner l'habitude おけば，やがては識見 discernement と善への愛 amour du bien とをもって行うように なるだろう」と考えられるからである（ルソー, 1762，『エミール』O. C., t. IV, pp. 339-340 全集第 六巻 pp. 119-120). 確かに教育の初期段階を画す る消極教育にあっては, どんな倫理的価值も直ち に実現させることはできないだろう。しかし，消 極教育過程において, 倫理的問題に子どもを馴染 ませることは十分可能であり, じっさい慣れさせ るべきことが主張されているのである.ルソーは, 消極教育においても，子どもに対する「善」への 積極的な方向づけの意図を，一定の慎重さととも に，明らかに有していたと言えるのである注 24).
ルソーの公教育論では，こうした積極的な価値 への習慣づけが，身体訓練という教育方法に求め られている。ただしそれらは，身体訓練そのもの によって直接的に実現されるのではない.むしろ 身体訓練は，倫理的目的に馴化させるための「場」 として位置づけられており, 間接的にこれらの価 值への志向性を担保しているのである。ルソーは, 上述の文脈において，身体訓練が採るべき形式に 言及しているが，それによれば，公教育での訓練 は「全員いっしょに tous ensemble, 衆人環視の場 で en public，つねに共通の目的 un but commun が あってみんながその達成を渇望 tous aspirent し, それが競争心 la concurrence と対抗心 l'émulation を 刺激する excite ような仕方で」なされねばならな いとしている（ルソー, 1771，『統治考』O.C., t. III, p. 968 全集第五巻 p. 378).ルソーによれば，公 教育において身体訓練が実施される際, 倫理的価 值を遠景に置くこうした諸条件の設定によって， はじめて子どもを「善い行為」へ「慣れさせる」 ことが可能となってくるのである.

ところで，こうした実践形態を導く目的性，す なわち公教育において希求される倫理的目的は, 前項での引用文に明らかなように，結局のところ， 「徳 la vertu」にあると言うことができる．もちろん， 徳そのものは消極教育によって直ちに獲得できる ものではないが，ルソー公教育論では，窮極的な 目的的契機として，教育の方向性を根本において 規定していると言える（橋本, 1990, pp. 445-453）. ルソーに拈ける「徳」についてはその多義性が指 摘されており（橋本, 1990, p. 446), 全体像を把握 することは容易ではないが，『政経論』において， 徳の定義に関わって公教育を基礎づける論議が展 開されており，われわれの課題においても注視す る必要があるだろう。すでに述べたように，ルソー 公教育論は政治論の範疇にあるが，両者の理論的 関係性はそこで浮き彫りにされているはずだから である。

ルソーでは国家における教育は, 『政経論』にお いて，「政府 gouvernement」が果たすべき三つの 「格率 maxime」のもとに明確な位置を与えられて いる。 三つの「格率」とは, 論述順に, (1)「一般 
意志 volonté générale」に従うこと，(2)「特殊意志 volonté particuliere」を「一般意志」に一致せしめ ること, (3)「公共の必要 besoins publics」を満た すことであり（ルソー, 1755, 『政経論』O.C., t. III, pp. 247-278 全集第五巻 pp. 70-103), 徳について は, 二番目の義務である「特殊意志」の「一般意 志」への一致の別名として定義されている（ル ソー, 1755, 『政経論』O. C., t. III, p. 252 全集第五 巻 p. $75 ＼mathrm{~ 注 ~}{ }^{25)}$.さらに, 徳を十分に実現させる 「もっとも有効」な手段として, 第 1 節でふれた 「祖国愛 l'amour de la patrie」が言及されており (ルソー, 1755, 『政経論』O. C., t. III, p. 254 全集第 五巻 pp. 77-78), 公教育は, この「祖国愛」を育 成する課題を担うものとして, 政府の「根本原理 の一つ」として定位されているのである（ルソー, 1755，『政経論』O. C., t. III, pp. 260-261 全集第五 巻 p. 84) 注 26).

さらに，ルソーは「われわれは人民が有徳であ ること vertueux を欲するのか. それならば，彼ら に祖国を愛させること aimer la patrie から始めよ う」と述べ（ルソー, 1755, 『政経論』O. C., t. III, p. 255 全集第五巻 p. 79), 「徳」に対する「祖国愛」 の有効性を強調している。他方, 『統治考』にお ける「教育」の項目では, 冒頭で,「これは重要 項目である. 人々に民族的な力を与え, 彼らが性 向からも, 情念からも, 必然性から見ても愛国者 patriotes となるほどまでに，その見解と嗜好を導 くべきものは, 教育 l'éducation である」と述べる ことで（ルソー, 1771, 『統治考』O. C., t. III, p. 966 全集第五巻 p. 376), 公教育における消極教育が含 意する目的性が，より限定的には「祖国愛」にあ ることを明らかにしている。したがってルソーに 打ける公教育の意義は, 祖国愛の育成を通して徳 の実現に寄与することにある，ということができ るのである.

ただし，こうした祖国愛の成立は，徳と同様， 成人の段階にある市民において初めて可能になる ものであり，これまで見てきた公教育の過程にお いて十全な達成を見ることはない. ルソーにあっ ては, 子ども期における教育はあくまでも「消極 的」であるべきであるし，そもそも子どもという
存在性自体が祖国愛の成立を可能としていないの である．公教育は，たしかに子ども期にすでに始 められねばならないのだが，まずは「慣れさせる」 ことで子どもを「祖国愛」へと方向づけることに 留まるのである。そして「身体訓練」は，これら 複合的な目的性のもとで，ルソー自身によって可 能かつ具体的な方法論としての位置を与えられて いるのである.

こうして本稿で注目した「身体訓練」は，ル ソー政治論および公教育論において，「祖国愛」を 抱く「市民」を育成する機能の一部を担うものと して正当に位置づけることができる。「身体訓練」 は, 公教育の意図と消極教育による制限との均衡 の上に成立する具体的な教育方法と言うことがで きるのである.

\section{まとめと今後の展望}

本研究は, ジャン = ジャック・ルソーを近代体 育が成立するための思想的基盤を準備した先駆者 と捉え, 体育概念を構成する二大要素である「教 育」と「身体」の連関性に着目するという方法論 により，「前一体育的」状況における実相を明ら かにしようとした。 こうした課題を遂行するため, 本稿では, 特にルソーにおける公教育論に焦点を 合わせ，そこに立ち現れる「身体」に関する記述 を分析し考察することによって, 公教育の「目 的一方法連関」のなかで身体性が担う役割を明確 化することを企図した。

考察の結果，これまで「ルソー体育論」と一括 されてきた公教育での「身体訓練」は，身体性か つ倫理性に関わる複合的目的を担う教育方法とし て位置づけられており，ルソー教育思想の中心概 念である「消極教育」の論理によって複合的目的 に対する教育方法としての妥当性を保証されてい るのであった。ルソーは, 被教育者の「子ども」 について, 未だ理性の発現を見ず, 知的な対象や 社会的・道徳的な関係性を認識し得ない存在であ ると理解しており, だからこそ彼らは消極教育に よって悪徳や誤謬から守られねばならないと見る。 ただし, 子どもは単なる受動的存在ではなく, 彼 
らの身体にはもともと運動を志向する推進力があ ることも，ルソーは認めていたのである.

また，公教育はそもそも「祖国愛」の育成を主 要な課題とするものであり，「身体訓練」もその育 成過程のうちに位置づけられるものであった。本 稿で注目した「身体訓練」の文脈は, ルソー政治 論ないし公教育論のうちに，「祖国愛」を抱く「市 民」を育成する機能の一部を担うものとして位置 づけられていたのである。しかし，消極教育の射 程にある身体訓練は, 祖国愛の育成を直ちに達成 することはない。あくまでも子どもにおける身体 性の育成に関わりつつ，祖国愛といった倫理的目 標に対しては準備教育としての役割のみが附与さ れているのである。つまり身体訓練は，公教育の 意図と消極教育による制限との均衡の上に成立す る具体的な教育方法と言うことができるのである.

以上のように，ルソーの公教育論における身体 性は，複合的な「目的一方法連関」のもとに置か れていることが明らかとなったが，今後検討され るべき論点もなお残されている。ルソー公教育論 においては，本稿で見た「身体訓練」が最終的に は市民および習俗を維持するための「祭り」へと 昇華すべきことが指摘されており，公教育での身 体訓練は，いわば「祭りの舞台装置」となるとさ れるのである。ルソーにおける「祭り」は，これ までもしばしば議論の沮上に載せられてきている が (坂倉, 1998; 吉岡, 1995; Baczko, 1974)，本研究の 展望においてもやはり注目すべき主題なのである. 本稿で見た「身体と教育」の諸相は，こうしたよ り広い地平に再定位される可能性を胚胎している のである.

ルソー思想への「身体と教育」を視点とするア プローチは，「前一体育的」な思想状況においてな お一定の体育的思想を抽出しうる可能性を明らか にするとともに，体育が制度的な独立性ないし自 律性を確立する前段階において，「祭り」などの社 会的・政治的な主題へと連続的にアプローチでき る柔軟性を有しているのである。

\section{注}

注 1）わが国の「体育」は，そもそも"physical education” を原語として明治期に成立した翻訳語であるが，こ れに相当する欧語の用例としては，筆者実見の限り では，Ballexserd（1762）が最古である.

注 2）岸野（1985, p. 25）は，同じ用例が 16 世紀にまで 遡る可能性を示唆するが，根拠は不明である。

注 3）「体育」に関しては，すでに古代ギリシア期の思 想的作品において，現代の「体育」にも相当する概 念内容が確認されており，用語としては「ギュムナ スティケーgymnastike」を見ることができる。しか し字義的には，「ギュムナスティケー」は「裸の訓 練」ほどのものであり，近代以降に成立した「身体 （的）教育」としての 'physical education'とは明確に 異なっている。林・笛木（1994）を参照のこと。な 㧍本稿では，さしあたり用語の成立を概念成立の要 件と見て，両者が一致する状沉を「用語／概念」と 表記する，ただし，近代の「体育」については，こ れまでに内実の多義化が指摘されており，その歴史 的な概念内容を見定めるためには，今後，十分な実 証的な検討が必要と思われる。

注 4）筆者は，「身体」に関する以上の点についてすで に論じてある。佐々木（2004）を参照.

注 5）底本には Gagnebin et Raymond（1959-1995）を用 いた。邦訳には，小林ほか（1978-83）を参照した が，手を加えた部分もある。本文中の表記では，通 例に従い，前者を'O.C.'，後者を「全集」と略記し， それぞれ巻数, 頁数を付し, 著書名は二重括弧内に 邦語で併記した。

注 6）それぞれの著作の性格，位置づけに関しては，『全 集』第五巻所収の阪上孝，永見文雄らによる「解説」 （1979）; Vaughan（1962 reprint)；小林（1996）なよ゙ を参照した。

注 7）ルソー教育論の主要な議論は，私教育論たる『エ ミール』を中心に展開されている。

注 8) Château（1969,p. 150）を参照.なお，ルソーにお いて私教育に対する公教育の優位を認める論者とし ては，他に，前掲 Vaughan（1962）; 新堀（1979）の ほか，梅根（1968）；川瀬（1971）らがいる.

注 9）「ルソー問題」とは，言うまでもなく，Cassirer （1932）が提出したルソー解釈に関わる方法論上の 問いである.カッシーラー（1997）は，ルッー思想 
に認められる「多様性」ないし「矛盾」を, 二項対 立的な図式によって読み解くことの妥当性を問うの だが, 本論で指摘した二つの教育形態を巡る問い は, まさしくこの範疇に属するものと言える. Rang （1964）；細川（2007）などを参照.なお，上で見た， 「ルソーは公教育と私教育のどちらに優越性を認め ていたか」という問いや，「公教育論と私教育論の 統一的理解はいかに可能か」という問い，あるいは 「人間」「市民」の概念内容への問いなどは，その派 生的な問題とも見ることができる．森田（1975）; 江坂（1973）などを参照.

注 10）橋本（1990, pp. 292-300）は, ルソー教育思想全 体における教育目的を摘出し, 公教育および私教育 をこれを達成するための教育方法と位置づけ,「柱」 と見ている。

注 11）同著作の出版は，ルソーの死後の 1782 年である が, 本稿での記載には決定稿が完成したとされる 1771 年を採る.

注 12）なお，公教育が論ぜられる二つの著作，すなわち 『政経論』『統治考』での “corps”の用例（形容詞 “corprel”を含む）は，前者に 12 例，後者に 65 例， 確認できる，このうち，人間の身体と解しうるもの はそれぞれ 4 例, 10 例である. ただし, 前者では 4 例すべてが政治体を説明するために類比的に言及さ れたものであるから，「身体」を教育と関わらせて 議論しようとするなら, むしろ後者の用例がより注 目されるべきである，実際，本稿での議論の主題と なる文脈は，これら後者の用例に関わるものである. なお，用例の検索に際しては, Brunet et Launay （1986）を参照した。

注 13）邦訳『全集』に従い，本論では “moral”に「倫理 的な」の訳語を採るが，むしろ「精神的な」ほどの 訳が適切かもしれない，今後の検討課題である.

注 14）ルソー（1980,『エミール』. O.C., t. IV, p. 272 全 集第六巻 p. 46）は次のように述べている。「体質と 健康を強化する renforcer le tempérament et la santé た めに, 手仕事 des travaux manuels と身体の訓練 des exercices du corps が有益なことを, ながながと証明 するのに筆をとめることはすまい，異議をとなえる ものはだれひとりとしてないことだからだ」.

注 15）白水社版『全集』では, ここでの 'des exercices' には「運動」の訳語が用いられており, 文意解釈上 妥当とも思われるが, 本稿では用語の統一性の観点 から，「訓練」を用いた。
注 16)『手紙』は,「ボーモン Beaumont」の名で出され た『エミール』を断罪する『教書』への反論と弁明 を旨とする書である。西川（1982, 全集第七巻所収 「解説」) を参照.

注 17）ルソー（1980,『エミール』. O. C., t. IV, p. 316 全 集第六巻 p. 94）によれば，「理性」の働きをとおし て人間は,「社会関係 des rélations sociales」や「道 徳性 la moralité」の認識へも導かれうる。ただし, 「理性」そのものの発現には, 感受性の展開が前提 となる。なお，小宮（1978, p. 154）は，第四段階へ の移行の「根源的契機」として,「性的意識の目覚 め」を指摘しており，これによって子どもは初めて， 「社会的な存在」になるとしている.

注 18）ルソー（1982,『ボーモンへの手紙』. O.C., t. IV, p. 945 全集第七巻 p. 462）を参照.また，原（1975）; 林（1978）などをも参照した。なお，「消極教育」 という用語はルソー自身のものではないようである. 注 19）沼田（1986）；橋本（1971）などを参照した。 そ れぞれの年齢区分は，第一期が 0-5 歳，第二期が 12 歳まで, 第三期が 15 歳まで, 第四期が 20 歳まで, 第五期がそれ以降とされているが，ただし，論者に よってその捉え方には幅がある.

注 20）身体の「推進力」は，いわば学習者の主体的な動 機であり，私見では，ルソーにおいて身体と教育を 結びつける決定的な紐帯である.

注 21）『エミール』での教育が, 所与の社会から距離を 保って設定されることは直ちに看取されることであ る。林（1995）は，他の人間あるいは社会から離れ ようとするルソーの「態度」を「分離化の原則」と 定義し, 消極教育の前提に位置づけている.

注 22）なお，公教育が「身体訓練」に求めたもう一つの 目的，身体の「強健」「健康」屯また，この過程に おいて同時に達成されうることはすでに明らかと思 われる。「健康 la santé と立派な体格 la bonne constitution とを, 彼の教育によって得られた利点の一つ に, いやむしろ, 教育によって彼に保存しえた自然 のたまもの dons de la nature の一つに，あつかましく 屯数えることができると私は思っている」.ルソー （1980，『エミール』. O.C., t. IV, p. 536 note 全集第六 巻 p. 375, 原注 (78) ) を参照.

注 23）実際たとえば坂入（1973, p. 104）はここでの 「体育」の役割として,「德性涵養」を挙げ,「公共 心や市民性を実践的に身につけよう」とするもので あると主張しており, Château（1969, p. 147）む，ル 
ソー公教育での「体育 l'éducation physique」を, 「道 徳教育 éducation morale」と総括している.いずれ の議論も,「体育」という用語の適否は措くとして 屯, 本稿の観点においては, 誤解を招くものと言わ ざるを得ない，また，『エミール』における「自然 に従う教育」と公教育の過程における論述の差異に 注目し，これをルソー教育思想における一貫性の 「欠如」などとして, 否定的に取り上げる論者もあ る. それらの立場からすれば，上で提起した問いは， ルソー自身の不首尾によって説明づけることもでき るかもしれない.しかし，この問いは，「消極教育」 の論理において十分に説明可能と思われる.

注 24）前項で見たように，『ボーモンへの手紙』では, より慎重に，「子どもをなじませておく dispose l'enfant」と述べられているが，上と同様の意図を読み 取ることができる.

注 25）ルソー（1979,『政経論』. O. C., t. III, p. 245 全集 第五巻 p. 67）によれば「一般意志」とは,「政治体 le corps politique」全体を導く一つの意志であり， 「つねに全体および各部分の保存と安楽をめざす」も のである。他方,「特殊意志」は政治体の各構成員 が持つ個別的な意志とも言うべきものである.

注 26）なお, ルソー（1979, 『社会契約論』. O. C., t. III, pp. 361-362, p. 396 全集第五巻 p. 122, 164）が，いわ ゆる「国家 Etat」と「政府 Gouvernement」とを概 念的に峻別していることには注意しておく必要があ ろう。前者は,「社会契約」によって成立する, 全 成員を包括する「公的人格 personne publique」であ り，後者は，「市民 Citoyens」の両面である「主権 者 Souverain」と「臣民 Sujet」とをつなぐ「中間団 体 un corps intermédiaire」である.

\section{文献}

Baczko, B: Claire, B. L. (1974) Rousseau, solitude et communauté. Mouton: Paris.

Ballexserd, J. (1762) Dissertation sur l'éducation physique des enfants, depuis leur naissance jusqu'à l'âge de puberté. Vallat-La-Chapelle: Paris.

Brunet, E. et Launay, L. (1986) Index des considérations sur le gouvernment de pologne et Index-concordance du projet de constitution pour la corse de J.-J.Rousseau. Editions Slatkine: Genève-Paris.

カッシーラー, エルンスト：生松敬三（1997）ジャン =
ジャック・ルソー問題. みすず書房 : 東京. 〈Cassirer, E. (1932) Das Problem Jean-Jacques Rousseau. Archiv für Geschichte der Philosophie 41: 177-213; 479-513. >

Château, J. (1969) Jean-Jacques Rousseau-sa philosophie de l'éducation-. Librairie Philosophique J. Vrin: Paris.

江坂 正（1973）ルソーの教育思想一「公教育」論につ

いて一。立命館文学 334/335: 1-25.

Grimsley, R. (1973) The philosophy of Rousseau. Oxford University Press: London-Oxford-New York.

原 聡介（1975）消極教育の課題と論理一ルソーは近代 教育の父か一、梅根悟監修・世界教育史研究会編 世 界教育史大系 10 フランス教育史 II. 講談社：東京, pp. 285-305; 323-326.

橋本三太郎（1971）特殊教育方法論における「感覚訓 練」の占める位置一ジャン・ジャック・ルソーの感覚 教育論をたずねて一，弘前大学教育学部紀要, 26: 2535.

橋本三太郎（1990） ルソー教育学の形成に関する研究. 風間書房 : 東京.

林英彰・笛木寛（1994）プラトンにおけるギュムナス ティケーおよび同系派生語の用例分析. 体育原理研 究, 25: 21-34.

林 幹夫（1978）自然人から有徳人への教育一ルソーの

「消極教育」原理について一. Philosophia, 66: 105-130.

林 信弘（1995）「エミール」を読む一ルソー教育思想 入門一. 法律文化社 : 京都.

細川亮一 (2007) 純化の思想家ルソー. 九州大学出版 会 : 福岡.

五十嵐顕ほか編（1990）岩波教育小辞典. 岩波書店：東 京.

川瀬八州夫（1971）近代教育思想史. 垣内出版 : 東京. 木下秀明（1971）日本体育史研究序説. 不昧堂出版：東 京.

岸野雄三（1985）体育史. 大修館書店：東京.

小林 浩（1996）ルソーの政治思想一「社会契約論」か

ら「ポーランド統治考」を読む一. 新曜社 : 東京.

小宮 彰（1978）ルソーと不可逆の《時》. 思想, 648:

151-169.

桑原武夫ほか（1977）ルソー研究（第二版）。岩波書 店：東京.

森田伸子（1975）近代教育の課題とルソー教育思想の構 造. 梅根悟監修・世界教育史研究会編 世界教育史 大系 10 フランス教育史 II. 講談社 : 東京, pp. 271284; 321-323. 
成田十次郎ほか（1975）体育史，梅根悟監修・世界教育 史研究会編 世界教育史大系 31 . 講談社 : 東京.

沼田裕之（1986）ルソーの人間観 (再版). 風間書房 : 東京.

Rang, M. (1964) L'éducation publique et la formation des citoyens chez J.-J. Rousseau. In: Université de Dijon (ed.) Études sur le contrat social de Jean-Jacques Rousseau. Société Les Belles Lettres: Paris, pp. 253-262.

Rousseau, J.-J.: Gagnebin, B. et Raymond, M. (éds.) (19591995) Euvres complètes de Jean-Jacques Rousseau (5 vols.). Bibliothèque de la Pléiade: Paris.

ルソー：小林善彦ほか（1978-83）ルソー全集（全 14 巻 別巻 2). 白水社 : 東京.

坂入 明 (1973) ルソーの体育思想について一近代体育 思想の一源流として一. 東京学芸大学大学院教育学研 究集録 1973(4): 94-108.
坂倉裕治（1998）ルソーの教育思想. 風間書房 : 東京. 佐々木究 (2004) J. J. ルソーの身体思想. 体育科学修士 論文 : 筑波大学.

新堀通也（1979）ルソー再興. 福村出版 : 東京.

The Oxford English Dictionary (Supplement,1981) (vol. 3). Oxford university press: New York.

Ulmann, J. (1982) De la Gymnastique aux Sports modernes. Librairie Philosophique J. Vrin: Paris.

梅根 悟（1968）西洋教育思想史 2 国民教育思想の時 代. 誠文堂新光社：東京.

Vaughan, C. E. (1962 reprint) The political writings of Jean Jacques Rousseau (Vol. I, II). Basil Blackwell: Oxford. 吉岡知哉（1995）ジャン =ジャック・ルソー論. 東京大 学出版会 : 東京.

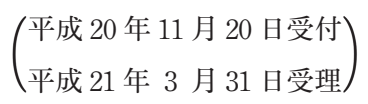

